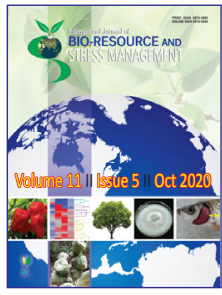

\title{
Integrated Nitrogen Management Influences the Yield Performance of Rice under Different Methods of Cultivation
}

\author{
A. L. Jat ${ }^{*}$, V. K. Srivastava ${ }^{2}$, S. K. Chongtham ${ }^{3}$ and Rajesh Kumar Singh ${ }^{2}$
}

${ }^{1}$ Castor-Mustard Research Station, S.D. Agricultural University, Sardarkrushinagar, Gujarat (385 506), India

${ }^{2}$ Dept. of Agronomy, Institute of Agricultural Sciences, Banaras Hindu University, Varanasi, Uttar Pradesh (221 005), India

${ }^{3}$ Multi Technology Testing Centre and Vocational Training Centre, CAEPHT, CAU, Ranipool, Sikkim (737 135), India

Open Access

Corresponding Author

A. L. Jat

e-mail: aanandiagro508@gmail.com

Citation: Jat et al., 2020. Integrated nitrogen management Influences the Yield Performance of Rice under Different Methods of Cultivation. International Journal of Bio-resource and Stress Management 2020, 11(5), 472-481. HTTPS://DOI. ORG/10.23910/1.2020.2152.

Copyright: (c) 2020 Jat et al. This is an open access article that permits unrestricted use, distribution and reproduction in any medium after the author(s) and source are credited.

Data Availability Statement: Legal restrictions are imposed on the public sharing of raw data. However, authors have full right to transfer or share the data in raw form upon request subject to either meeting the conditions of the original consents and the original research study. Further, access of data needs to meet whether the user complies with the ethical and legal obligations as data controllers to allow for secondary use of the data outside of the original study.

Funding: The funds for this research work are provided by Indian Council of Agricultural Research, New Delhi, India.

Conflict of interests: The authors have declared that no conflict of interest exists.

Acknowledgement: The first author is grateful to Indian Council of Agricultural Research, New Delhi for the award of ICAR-Senior Research Fellowship as a financial assistance during Ph.D. programme to carry out this work.

Article History

RECEIVED in $09^{\text {th }}$ September 2020 RECEIVED in revised form $19^{\text {th }}$ October 2020 ACCEPTED in final form $30^{\text {th }}$ October 2020

\begin{abstract}
The field studies were conducted during 2012 and 2013 at Banaras Hindu University, Varanasi, Uttar Pradesh, India. The experiments were undertaken on two rice hybrids cultivated under two different establishment techniques with integrated nitrogen management to evaluate the growth dynamics, production potential and nutrient removal of rice. Results revealed that the system of rice intensification (SRI) and rice cv. Arize-6444 recorded significantly higher growth attributes viz., number of tillers hill ${ }^{-1}$, dry matter accumulation, crop growth rate and relative growth rate with almost yield attributes and yield with nutrient harvest index and total water productivity. The corresponding increment in grain and straw yield of rice under SRI to the tune of $14.66 \%$ and $13.12 \%$ over normal transplanting and rice hybrid Arize 6444 produced $8.63 \%$ and $5.32 \%$ higher grain and straw yield over PHB 71, respectively. Among the integrated nitrogen management practices, the application of $50 \% \mathrm{RDN}+50 \% \mathrm{~N}$ through FYM+Azospirillum recorded significantly higher growth attributes, grain yield $\left(6942 \mathrm{~kg} \mathrm{ha}^{-1}\right)$, protein content $(7.80 \%)$, nutrient content, protein yield (542 kg $\left.\mathrm{ha}^{-1}\right)$ total nutrient uptake, total water productivity $(5.90 \mathrm{~kg} / \mathrm{ha}-\mathrm{mm})$ and nutrient harvest index of rice. The study concluded that the conjunctive application of inorganic fertilizer and organic manure with biofertilizer to rice hybrid 'Arize-6444' cultivation under SRI method for realizing higher yield of rice in eastern Uttar Pradesh.
\end{abstract}

Keywords: Rice, Azospirillum, CGR, hybrids, nitrogen and spikelet sterility

\section{Introduction}

Rice cultivation is in crisis the world over and India with a shrinking area, reducing water availability, fluctuating annual production, stagnating yields and escalating input (Thakur et al., 2016). The production cost of paddy has consistently been increasing owing to the escalating costs of seeds, fertilizers, labour and other inputs. With increasing labour scarcity due to urbanization, sustaining the interest of farmers in rice cultivation has become a challenge. Amongst production resources, water and nitrogen have especial role in increasing rice production. Global availability of water was $3500 \mathrm{~m}^{3}$ person $^{-1}$ year ${ }^{-1}$ in 1950, which reduced to $1250 \mathrm{~m}^{3}$ person ${ }^{-1}$ year $^{-1}$ in 2003 and is estimated to be $760 \mathrm{~m}^{3}$ person $^{-1}$ year $^{-1}$ in 2050 (Prasad and Nagrajan, 2004). Irrigated agriculture 
utilizes about $90 \%$ of fresh water and out of which $>50 \%$ is used for rice cultivation (Jat et al., 2016). Water scarcity is becoming more a global concern and signal of serious water scarcity are already evident in several agricultural areas. Besides this increasing threat to productivity of irrigated rice systems due to water scarcity, rice has very low wateruse efficiency under irrigated conditions. It consumes approximately 3000-5000 litre of water to produce one $\mathrm{kg}$ of rice. In India, rice cultivation consumes $80 \%$ of the total water available for agriculture. About $50-80 \%$ of total water applied to rice fields is lost as deep percolation, while only $30-40 \%$ is utilized consumptively. Increasing scarcity due to increasing demand for water from other sectors threatens the sustainability of irrigated rice production and calls for development of novel technologies that require less water than conventional flooded rice without experiencing yield losses (Kadiyala et al., 2012; Singh, 2013). There is clearly an urgent need to find ways to grow more rice with less water and fewer inputs. One way to address the dearth of water for rice production would be to shift from conventional methods of rice cultivation to apply the system of rice intensification (SRI). SRI has numerous advantages over the conventional system of rice production. It increases rice grain yield by at least $50 \%$ (Lin et al., 2005), save seeds by at least $80-90 \%$ (Miyazato et al., 2010), save water by at least 50\% (Satyanarayana et al., 2007 ) or $67 \%$ (Lazaro, 2004), as well as reducing the cost of rice production. This innovative method of rice cultivation, by requiring only intermittent and light irrigations that can reduce the water demand and percolation losses from rice fields. SRI is gaining popularity in the country in recent past but so far, no specific nutrient management strategy has been developed or recommended for SRI. Continuous, imbalanced and high level use of chemical or inorganic fertilizers had led to soil degradation problems, which are proving detrimental to rice production i.e. declining trend in the productivity of rice even when grown under adequate $\mathrm{N}, \mathrm{P}$ and $\mathrm{K}$ application (Jat et al., 2016; Saravanakumar, 2020). Application of inorganic fertilizers alone could not sustain the soil fertility and productivity. Integration of organic sources such as FYM and biofertilizer may also help in the restoration of soil health (Pillai et al., 2007). The conjunctive application of organics with inorganic sources of nutrient reduces the dependence on chemical inputs, and it not only acts as a source of nutrient but also provides micronutrient as well as modifies the soil physical behaviour and increases the efficiency of applied nutrients (Pandey et al., 2007). Considering above facts in view the present field experiment was planned to study the effect of integrated nitrogen management on performance of rice hybrids under different methods of cultivation for agroclimatic region of eastern Uttar Pradesh.

\section{Materials and Methods}

\subsection{Experimental site and weather}

A field experiment was conducted during 2012 and 2013 at Banaras Hindu University, Varanasi (25⒈ $18^{\prime} \mathrm{N}$ latitude, $83^{\circ} 03^{\prime} \mathrm{E}$ longitude and at an altitude of $75.7 \mathrm{~m}$ above mean sea level) in the Northern-Gangetic alluvial plains having characteristics of sub-tropical climate. The crops received $691.5 \mathrm{~mm}$ of rainfall during 2012 and $825.0 \mathrm{~mm}$ in 2013 . The rainfall observed to be higher in initial stage but later it was uniformly distributed throughout the crop period during the second year. The weekly mean maximum temperature varied from 29.4 to $42.6^{\circ} \mathrm{C}$ (average $33.13^{\circ} \mathrm{C}$ ) and 26.7 to $38.0^{\circ} \mathrm{C}$ (average $31.73^{\circ} \mathrm{C}$ ) along with minimum temperature ranged from 16.3 to $30.6^{\circ} \mathrm{C}$ (average $25.28^{\circ} \mathrm{C}$ ) and 17.3 to $28.3^{\circ} \mathrm{C}$ (average of $25.17^{\circ} \mathrm{C}$ ) during 2012 and 2013, respectively. The weekly mean sunshine hours in 2012 was low (5.36 hours) as compared to 2013 (5.72 hrs.). The weekly mean rate of evaporation was less in second year (3.62 $\mathrm{mm}$ ) over first year ( $4.14 \mathrm{~mm})$, respectively. The soil is typic Ustochrepts with sandy clay loam texture ( $50.27 \%$ sand, $27.41 \%$ silt, and $22.32 \%$ clay), bulk density of $1.41 \mathrm{Mg} \mathrm{m}^{-3}$, and low in available nitrogen and phosphorus with medium in available potassium status (Table 1 ).

Table 1: Initial soil physico-chemical properties of the experimental field (0-20 cm soil)

\begin{tabular}{ccccccc}
\hline Year & $\mathrm{EC}^{*}\left(\mathrm{dS} \mathrm{m} \mathrm{m}^{-1}\right)$ & $\mathrm{pH}$ & $\mathrm{OC}^{\#}(\%)$ & Available N $\left(\mathrm{kg} \mathrm{ha}^{-1}\right)$ & ${\text { Available } \mathrm{P}_{2} \mathrm{O}_{5}\left(\mathrm{~kg} \mathrm{ha}^{-1}\right)}_{\text {Available K }_{2} \mathrm{O}\left(\mathrm{kg} \mathrm{ha}^{-1}\right)}$ \\
\hline 2012 & 0.18 & 7.39 & 0.34 & 205.20 & 25.30 & 215.60 \\
2013 & 0.17 & 7.41 & 0.35 & 213.21 & 25.86 & 219.80 \\
\hline
\end{tabular}

*: Electrical conductivity; \#: Organic carbon

\subsection{Experimental details}

The experiment was laid out in split-plot design replicated thrice with keeping 5.0 by 4.0 m plots. The treatments comprised two crop establishment methods (NT- Normal transplanting/traditional method and SRI- System of rice intensification) with two hybrids i.e. PHB-71 (duration 120130 days) and Arize-6444 (duration 130-140 days) as assigned to main plots. Each main plot were further divided into six sub-plots to accommodate integrated nitrogen management treatments, i.e. $\left(\mathrm{N}_{1}-100 \%\right.$ RDN, $\mathrm{N}_{2}-125 \%$ RDN, $\mathrm{N}_{3}-50 \%$
RDN+50\% N through FYM, $\mathrm{N}_{4}-50 \%$ RDN $+50 \% \mathrm{~N}$ through FYM+Azospirillum, $\mathrm{N}_{5}-100 \% \mathrm{~N}$ through FYM, $\mathrm{N}_{6}$-Control/No fertilizer).

\subsection{Crop management and observations}

The experimental field was ploughed with tractor drawn mould board plough followed by two harrowing. Before laying out the experiment the field was puddled for transplanting. Nursery bed of normal transplanting ( 23 days old seedlings) was raised fourteen days before the SRI nursery (10 days old seedlings) to synchronize the transplanting at a same 
time. Seedlings were treated with biofertilizer 'Azospirillum' by root deep in culture as per treatment. Two seedlings for normal transplanting and single seedling hill ${ }^{-1}$ for SRI along with soil was transplanted by using index finger or thumb and gently planted at the spacing was maintained at $20 \times 15$ $\mathrm{cm}^{2}$ under normal transplanting and $25 \times 25 \mathrm{~cm}^{2}$ under SRI plots in puddled soil on $5^{\text {th }}$ July, 2012 and $4^{\text {th }}$ July, 2013. Recommended dose of fertilizer i.e. 150, 75 and $60 \mathrm{~kg} \mathrm{ha}^{-1}$ $\mathrm{N}, \mathrm{P}_{2} \mathrm{O}_{5}$ and $\mathrm{K}_{2} \mathrm{O}$ for rice were applied as per treatments. Farmyard manure $\left(0.51 \% \mathrm{~N}, 0.26 \% \mathrm{P}_{2} \mathrm{O}_{5}\right.$ and $\left.0.50 \% \mathrm{~K}_{2} \mathrm{O}\right)$ was manually incorporated as per the treatments. Nutrient application was done as per treatments. Irrigation was given with the help of parshall flume only on appearance of hair line cracks. Weed management was done manually under normal transplanting method and conoweeding under SRI to reduce the weed infestation and other crop management practices were followed as per the standard recommendation. The field observations on plant height, number of tillers hill ${ }^{-1}$, dry matter accumulation, crop growth rate, relative growth rate, number of filled grains panicle ${ }^{-1}$, number of unfilled spikelets panicle ${ }^{-1}$, spikelet sterility percentage, protein contents, protein yield, grain yield, harvest index, water productivity, nutrient uptake and nutrient harvest index were recorded. The nutrient content were estimated from both seed and stover, separately during both years and its uptake were estimated with the help of total seed and stover yield multiply with respective nutrient content.

Crop growth rate and relative growth rate were computed between 30-60 and 60-90 DAT by the formulae given by (Redford, 1967).

Where, $W_{1}, W_{2}$ are dry matter and at time $t_{1}, t_{2}$, and $L n=$ Natural logarithm

Spikelet sterility (\%) was also calculated. Irrigation water was measured using a 'parshall flume'. The irrigation was applied to rice as per requirement, but also depended on the rainfall. The quantity of water applied and the depth of irrigation were computed using standard procedure. The input water productivity was computed as the ratio of grain yield to the total water input (irrigation+rainfall) from nursery raising to harvesting of the crop and expressed as $\mathrm{kg}$ grain ha $\mathrm{mm}^{-1}$. Protein content in grain was worked out by multiplying the nitrogen content in grain with the factor 6.25, as suggested by (AOAC, 1970). Protein yield was determined by multiplying the protein content in grain with their respective yields.

The nutrient harvest index was determined by Dass et al., 2010.

Nutrient harvest index $(\%)=\left(\right.$ Nutrient uptake by grain $\left(\mathrm{kg} \mathrm{ha}^{-1}\right) /$ Nutrient uptake by grain+straw $\left(\mathrm{kg} \mathrm{ha}^{-1}\right) \times 100$

\subsection{Statistical analysis}

The experimental data of two consecutive years were pooled and analyzed statistically by applying the technique of analysis of variance (Gomez and Gomez, 1984) prescribed for the split plot design to test the significant difference among treatments by the $\mathrm{F}$ test and conclusions were drawn at 5\% probability levels.

\section{Results and Discussion}

\subsection{Crop growth}

SRI planting recorded significantly higher plant height, number of tillers hill-1, dry matter accumulation hill ${ }^{-1}$, CGR between 30-60 DAT and RGR between 60-90 DAT over normal transplanting. However, CGR between 60-90 DAT and RGR between 30-60 DAT under both the crop establishment method could not influenced significantly (Table 2 ). This may be attributed under normal transplanting have 23 days old seedlings and in SRI only 10 days old seedlings were planted, consequently rapid growth of older seedling during initial stage under normal transplanting is well acknowledged thereafter at successive stage SRI produced more growth by their 10 days old tender age seedlings which obviously took more time to initiate better growth over normal transplanting (Singh, 2013). Significantly higher no. of tillers hill-1 was produced under SRI as compared to normal transplanting. However, tender age seedling showed better agronomic potential to produced significantly higher dry matter accumulation hill-1. Similar findings were earlier reported by (Krishna et al., 2008). SRI planting significantly increased by $13.34 \%$ and $16.50 \%$ more dry matter production hill $^{-1}$ over normal transplanting at 30 and 60 DAT. The current findings are parallel with the finding of (Chandrapala et al., 2010; Manjunatha et al., 2010). Amongst the two hybrids, no. of tillers hill-1 and dry matter accumulation hill ${ }^{-1}$ was significantly increased due to hybrid Arize-6444 over PHB-71. However, the tallest plant was recorded with $\mathrm{PHB}-71$. The differences in plant height among cultivars are mainly due to their genetic build up (Singh et al., 2013). However, relatively more tillers hill ${ }^{-1}$, dry matter, crop growth rateand relative growth rate were recorded with 'Arize-6444' and showed its significant superiority over 'PHB71 '. Differences have been observed in grain yield among plants or hybrids having the same amount of dry matter, because differences exist in the utilization of photosynthates among them (Hayashi, 1995). High efficient photosynthetic performance of super high-yielding rice hybrids to produce more no. of tillers hill- $^{-1}$, resulting in to more dry matter synthesis is largely due to the increased 'cytokinin' content in their roots (Shu-Qing et al., 2004) contributing to produced higher grain yield. Among integrated nitrogen management treatmentsthe application of $50 \%$ RDN $+50 \% \mathrm{~N}$ through $\mathrm{FYM}+$ Azospirillum produced higher plant height, no. of tillers hill $^{-1}$, dry matter accumulation hill-1 ${ }^{-1}$ CGR and RGR though it remained statistically at par with $125 \%$ RDN but significantly superior over rest of the treatments (Table 2). This might be due to combined application of inorganic fertilizer with FYM and biofertilizer facilitating better structure, texture, soil environment for root development and increased availability of nitrogen for longer period. The additional nitrogen fixed by Azospirillum was made available to plants. Similar results were also reported by (Rakshit et al., 2008; Sangeetha et al., 


\begin{tabular}{|c|c|c|c|c|c|c|c|c|c|c|}
\hline \multirow[t]{3}{*}{ Treatments } & \multicolumn{2}{|c|}{$\begin{array}{l}\text { Plant height } \\
\text { (cm) }\end{array}$} & \multicolumn{2}{|c|}{$\begin{array}{l}\text { Number of } \\
\text { tillers hill-1 at }\end{array}$} & \multicolumn{2}{|c|}{$\begin{array}{l}\text { Dry matter } \\
\text { accumulation } \\
\left.(\mathrm{g} \mathrm{hill})^{-1}\right)\end{array}$} & \multicolumn{2}{|c|}{$\begin{array}{c}\text { CGR } \\
\left(\mathrm{g} \mathrm{hill}^{-1} \text { day }^{-1}\right)\end{array}$} & \multicolumn{2}{|c|}{$\begin{array}{c}\text { RGR } \\
\left(\mathrm{mg} \mathrm{g}^{-1} \mathrm{day}^{-1}\right)\end{array}$} \\
\hline & 30 & 60 & 30 & 60 & 30 & 60 & $30-60$ & $60-90$ & $30-60$ & $60-90$ \\
\hline & DAT & DAT & DAT & DAT & DAT & DAT & DAT & DAT & DAT & DAT \\
\hline \multicolumn{11}{|l|}{ A. Crop establishment methods } \\
\hline Normal transplanting & 63.51 & 101.64 & 13.46 & 18.15 & 8.69 & 27.65 & 0.632 & 1.14 & 38.83 & 27.27 \\
\hline SRI & 57.87 & 96.84 & 15.94 & 21.90 & 9.85 & 32.21 & 0.746 & 1.21 & 39.43 & 24.04 \\
\hline SEm \pm & 0.447 & 0.711 & 0.169 & 0.216 & 0.119 & 0.312 & 0.009 & 0.034 & 0.407 & 0.675 \\
\hline $\mathrm{CD}(p=0.05)$ & 1.377 & 2.191 & 0.521 & 0.666 & 0.366 & 0.960 & 0.027 & NS & NS & 2.080 \\
\hline \multicolumn{11}{|l|}{ B. Hybrids } \\
\hline PHB-71 & 62.90 & 102.42 & 14.22 & 18.46 & 9.44 & 28.99 & 0.652 & 1.06 & 38.12 & 23.58 \\
\hline Arize- 6444 & 58.48 & 96.06 & 15.18 & 21.59 & 9.11 & 30.87 & 0.726 & 1.28 & 40.14 & 27.73 \\
\hline SEm \pm & 0.447 & 0.711 & 0.169 & 0.216 & 0.119 & 0.312 & 0.009 & 0.034 & 0.407 & 0.675 \\
\hline $\mathrm{CD}(p=0.05)$ & 1.377 & 2.191 & 0.521 & 0.666 & NS & 0.960 & 0.027 & 0.105 & 1.253 & 2.080 \\
\hline \multicolumn{11}{|l|}{ C. Integrated nitrogen management } \\
\hline $100 \%$ RDN & 61.92 & 103.43 & 15.38 & 20.82 & 10.25 & 33.23 & 0.766 & 1.20 & 38.52 & 24.59 \\
\hline $125 \%$ RDN & 63.65 & 104.29 & 16.48 & 22.95 & 11.19 & 33.43 & 0.742 & 1.27 & 36.26 & 25.19 \\
\hline $50 \%$ RDN $+50 \% \mathrm{~N}$ through FYM & 60.20 & 99.29 & 14.75 & 19.93 & 9.19 & 30.47 & 0.692 & 1.26 & 38.19 & 26.68 \\
\hline $\begin{array}{l}50 \% \mathrm{RDN}+50 \% \mathrm{~N} \text { through } \mathrm{FYM}+ \\
\text { Azospirillum }\end{array}$ & 64.49 & 104.90 & 16.87 & 23.30 & 10.58 & 34.45 & 0.796 & 1.28 & 39.51 & 24.37 \\
\hline $100 \%$ RDN through FYM & 58.73 & 93.77 & 13.88 & 18.58 & 7.86 & 27.32 & 0.649 & 1.14 & 41.59 & 26.85 \\
\hline Control (No fertilizer) & 55.17 & 89.78 & 10.84 & 14.58 & 6.05 & 20.69 & 0.488 & 0.89 & 40.68 & 26.25 \\
\hline SEm \pm & 0.473 & 0.836 & 0.138 & 0.505 & 0.114 & 0.340 & 0.011 & 0.036 & 0.461 & 0.714 \\
\hline $\mathrm{CD}(p=0.05)$ & 1.331 & 2.353 & 0.387 & 0.576 & 0.321 & 0.957 & 0.031 & 0.103 & 1.297 & NS \\
\hline
\end{tabular}

*DAT= Day after transplanting

2010; Saravanakumar, 2020).

\subsection{Yield performance and water productivity}

SRI planting significantly produced $8.57 \%, 14.66 \%$ and $13.12 \%$ more number of filled grains panicle ${ }^{-1}$, grain yield and straw yield with minimum unfilled spikelets panicle ${ }^{-1}$ (23.56) and sterility (11.54\%) as compared to normal transplanted rice (Table 3). Harvest index was remained equally effective due to both the establishment methods. This might be due to SRI seedling utilized phyllochronic potential to produce significantly higher grain and straw yield over normal transplanting. The irrigation water application depends on the total rainfall and its pattern of distribution. The highest water productivity $(5.59 \mathrm{~kg} / \mathrm{ha}-\mathrm{mm})$ was recorded in SRI followed by normal transplanting $(4.80 \mathrm{~kg} / \mathrm{ha}-\mathrm{mm})$ which was $14.13 \%$ higher over normal transplanting. Due to marked improvement in growth and yield attributes, likewise dry matter accumulation, panicles $\mathrm{m}^{-2}$ and grains panicle $\mathrm{e}^{-1}$ proved instrumental in increasing grain and straw yield under SRI. Improvement in yield attributes, yield and water productivity associated with SRI management proved conducive for increasing rice yields under irrigated production systems due to single seedling hill-1, young seedlings and moderate wetting and drying soil conditions. With SRI, the transplanting of young seedlings results in a prolonged period for more root development and tillering. Moreover, with young seedlings the transplanting shock will be minimal, while greatly reduced plant density over normal transplanting favour the development of a distinctly different plant phenotype. These findings are confirmed by (Thakur et al., 2013). Meanwhile, rice hybrid Arize-6444 out yielded over PHB 71 with recording significantly higher filled grains panicles ${ }^{-1}(183)$ and harvest index (42.95\%) along with minimum unfilled spikelet panicle ${ }^{-1}$ and sterility percent. Hybrids 'Arize-6444' showed great potential to exploit hybrids vigour to produce higher grain yield and showed marked superiority over 'PHB-71'. Data on grain yield revealed that 'Arize-6444' recorded significantly higher grain yield $\left(6365 \mathrm{~kg} \mathrm{ha}^{-1}\right)$ and straw yield (5859 kg ha-1) over 'PHB-71'. This hybrid also registered significantly higher 


\begin{tabular}{|c|c|c|c|c|c|c|c|}
\hline Treatments & $\begin{array}{l}\text { No. of } \\
\text { filled grains } \\
\text { panicle }{ }^{-1}\end{array}$ & $\begin{array}{l}\text { No. of unfilled } \\
\text { spikelet } \\
\text { panicle }^{-1}\end{array}$ & $\begin{array}{c}\text { Sterility } \\
(\%)\end{array}$ & $\begin{array}{c}\text { Grain } \\
\text { yield } \\
\left(\mathrm{kg} \mathrm{ha}^{-1}\right)\end{array}$ & $\begin{array}{c}\text { Straw } \\
\text { yield (kg } \\
\left.\mathrm{ha}^{-1}\right)\end{array}$ & $\begin{array}{c}\text { Harvest } \\
\text { index } \\
(\%)\end{array}$ & $\begin{array}{c}\text { Water } \\
\text { productivity } \\
\text { (kg/ha-mm) }\end{array}$ \\
\hline \multicolumn{8}{|l|}{ A. Crop establishment methods } \\
\hline Normal transplanting & 169.71 & 25.40 & 13.15 & 5695 & 7700 & 42.43 & 4.80 \\
\hline SRI & 184.27 & 23.56 & 11.54 & 6530 & 8711 & 42.73 & 5.59 \\
\hline SEm \pm & 2.342 & 0.263 & 0.063 & 58.4 & 62.4 & 0.197 & 0.050 \\
\hline $\mathrm{CD}(p=0.05)$ & 7.215 & 0.809 & 0.193 & 180.1 & 192.3 & NS & 0.154 \\
\hline \multicolumn{8}{|l|}{ B. Hybrids } \\
\hline PHB-71 & 170.46 & 25.35 & 13.06 & 5859 & 7993 & 42.21 & 4.98 \\
\hline Arize- 6444 & 183.51 & 23.61 & 11.63 & 6365 & 8419 & 42.95 & 5.41 \\
\hline SEm \pm & 2.342 & 0.263 & 0.063 & 58.4 & 62.4 & 0.197 & 0.050 \\
\hline$C D(p=0.05)$ & 7.215 & 0.809 & 0.193 & 180.1 & 192.3 & 0.608 & 0.154 \\
\hline \multicolumn{8}{|l|}{ C. Integrated nitrogen management } \\
\hline $100 \%$ RDN & 183.65 & 23.82 & 11.55 & 6485 & 8664 & 42.77 & 5.51 \\
\hline $125 \%$ RDN & 188.59 & 23.21 & 11.02 & 6597 & 8773 & 42.84 & 5.61 \\
\hline $50 \%$ RDN $+50 \% \mathrm{~N}$ through FYM & 181.51 & 24.86 & 12.13 & 6407 & 8498 & 42.96 & 5.45 \\
\hline $\begin{array}{l}50 \% \mathrm{RDN}+50 \% \mathrm{~N} \text { through } \mathrm{FYM}+ \\
\text { Azospirillum }\end{array}$ & 193.35 & 22.07 & 10.32 & 6942 & 9158 & 43.13 & 5.90 \\
\hline $100 \%$ RDN through FYM & 171.15 & 25.60 & 13.05 & 5909 & 7916 & 42.73 & 5.02 \\
\hline Control (No fertilizer) & 143.66 & 27.30 & 16.01 & 4334 & 6225 & 41.03 & 3.68 \\
\hline SEm \pm & 1.847 & 0.237 & 0.072 & 62.0 & 68.2 & 0.261 & 0.053 \\
\hline$C D(p=0.05)$ & 5.199 & 0.666 & 0.203 & 174.5 & 192.1 & 0.734 & 0.149 \\
\hline
\end{tabular}

${ }^{*} \mathrm{DAT}=$ Day after transplanting

water productivity as compared to PHB-7, respectively. These results are in close conformity with the earlier findings of (Choudhary et al., 2013; Gupta et al., 2011; Jat et al., 2015; Jat et al., 2016; Vishwakarma et al., 2016). Production potential, vigourness (genetic traits) and physiological efficiency of hybrid are responsible to differentiate it from other hybrids in their growth habits, rooting pattern, input utilization and resistance development against insect pest and diseases that ascribed to harvest optimum yield under a definite set of agroclimatic condition (Shukla et al., 2015; Jagtap et al., 2018). The application of $50 \% \mathrm{RND}+50 \% \mathrm{~N}$ through $\mathrm{FYM}+$ Azospirillum brought about marked improvement in filled grains panicle ${ }^{-1}$ and grain yield of rice and also recorded significantly lowest unfilled spikelet panicle ${ }^{-1}$ and sterility percent over remaining treatments. Combined application of $50 \%$ RND $+50 \% \mathrm{~N}$ through FYM+Azospirillum had a total water productivity of $5.90 \mathrm{~kg} / \mathrm{ha}-\mathrm{mm}$, whereas control treatment had a lowest water productivity of $3.68 \mathrm{~kg} / \mathrm{ha}-\mathrm{mm}$ as two years pooled data basis. It is might be due to cumulative effect of organic sources combined with inorganic and bio fertilizer resulted more contribution in photosynthesis. Plants remained green for longer time with increase in nitrogen release for longer period contributed in production of carbohydrates from current photosynthates for increased number of filled grains panicle ${ }^{-1}$, coinciding with more sunshine hours for increased photosynthetic products to fill better sink resulting in higher filled grain panicle ${ }^{-1}$ (Pandey et al., 2007). Significant positive linear relationships between filled grains panicle ${ }^{-1}$ and number of panicles $\mathrm{m}^{-2}$ with grain yield were observed with the respective values of $r^{2}=0.884$ (Figure 1 ) and $r^{2}=0.800$ (Figure 2). The number of panicles $\mathrm{m}^{-2}$ and filled grains panicle ${ }^{-1}$ increased as rice yield increased, while an inverse trend was observed with unfilled spikelets panicle ${ }^{-1}$ and sterility percent with grain yield with the value of $r^{2}=0.531$ (Figure 1) and $r^{2}=0.801$ (Figure 2). Yield is a function of complex interrelationships of its components, which are determined from the growth rhythms in vegetative phase and its subsequent reflection in reproductive phase of the plant. These results are in agreement with the findings of (Alim, 2012; Islam et al., 2012; Jat et al., 2016).

\subsection{Protein content and protein yield}

Protein content (7.74\%) and protein yield $\left(507 \mathrm{~kg} \mathrm{ha}^{-1}\right)$ was recorded significantly higher (Table 4) under SRI planting over 


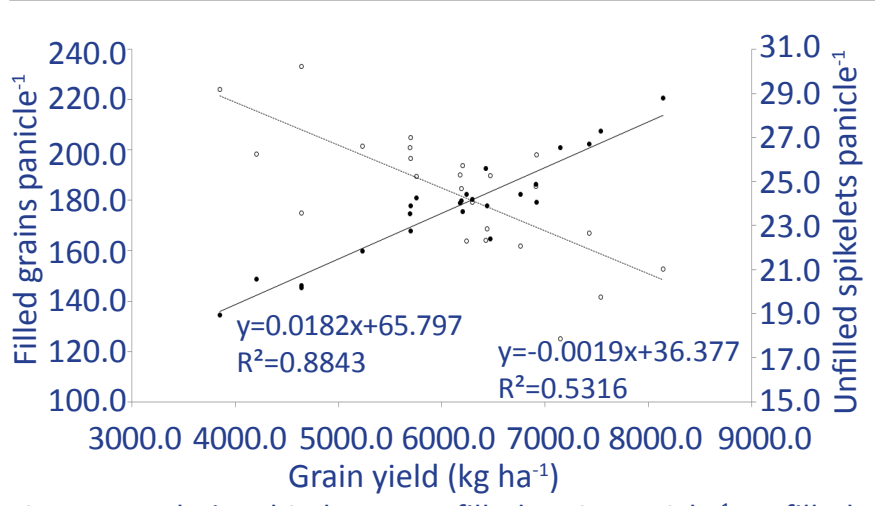

Figure 1: Relationship between filled grain panicle ${ }^{-1}$, unfilled grain panicle ${ }^{-1}$ and grain yield of rice. Positive correlations are represented by closed symbol and negative correlations are represented by open symbols (Mean data of two years)

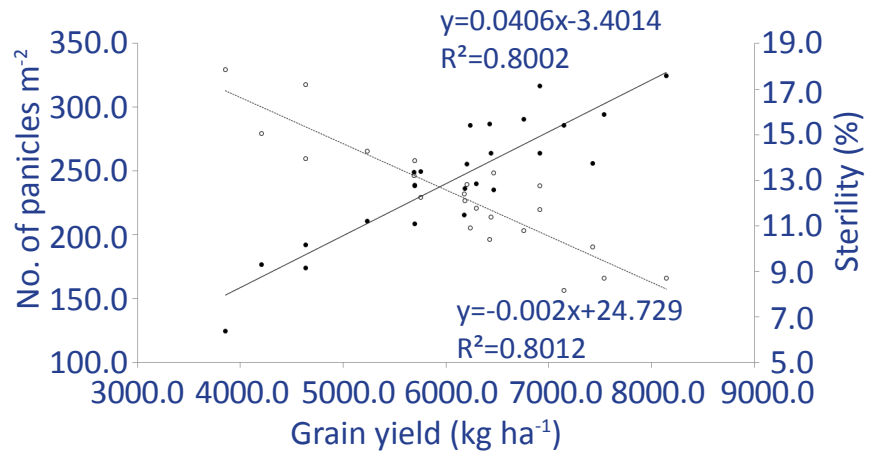

Figure 2: Relationship between number of panicles $\mathrm{m}^{-2}$, sterility (\%) and grain yield of rice. Positive correlations are represented by closed symbol and negative correlations are represented by open symbols (Mean data of two years)

Table 4: Effect of crop establishment methods, hybrids and nitrogen management on nutrient content in rice (Pooled data of 2 years)

\begin{tabular}{|c|c|c|c|c|c|c|c|c|}
\hline \multirow[t]{2}{*}{ Treatments } & \multirow{2}{*}{$\begin{array}{c}\text { Protein } \\
\text { content (\%) }\end{array}$} & \multirow{2}{*}{$\begin{array}{l}\text { Protein yield } \\
\left(\mathrm{kg} \mathrm{ha}^{-1}\right)\end{array}$} & \multicolumn{2}{|c|}{ Nitrogen (\%) } & \multicolumn{2}{|c|}{ Phosphorus (\%) } & \multicolumn{2}{|c|}{ Potassium (\%) } \\
\hline & & & Grain & Straw & Grain & Straw & Grain & Straw \\
\hline \multicolumn{9}{|l|}{ A. Crop establishment methods } \\
\hline Normal transplanting & 7.40 & 422 & 1.185 & 0.612 & 0.202 & 0.094 & 0.239 & 1.452 \\
\hline SRI & 7.74 & 507 & 1.238 & 0.617 & 0.213 & 0.097 & 0.248 & 1.559 \\
\hline SEm \pm & 0.03 & 3.54 & 0.005 & 0.0008 & 0.0011 & 0.0005 & 0.002 & 0.0082 \\
\hline $\mathrm{CD}(p=0.05)$ & 0.10 & 10.90 & 0.0153 & 0.0023 & 0.0034 & 0.0016 & 0.005 & 0.0252 \\
\hline \multicolumn{9}{|l|}{ B. Hybrids } \\
\hline PHB-71 & 7.61 & 447 & 1.217 & 0.616 & 0.209 & 0.097 & 0.246 & 1.512 \\
\hline Arize-6444 & 7.67 & 482 & 1.206 & 0.614 & 0.206 & 0.095 & 0.240 & 1.498 \\
\hline SEm \pm & 0.03 & 3.54 & 0.005 & 0.0008 & 0.0011 & 0.0005 & 0.002 & 0.0082 \\
\hline $\mathrm{CD}(p=0.05)$ & NS & 10.90 & NS & NS & NS & 0.0016 & 0.005 & NS \\
\hline \multicolumn{9}{|l|}{ C. Integrated nitrogen management } \\
\hline $100 \% \operatorname{RDN}$ & 7.61 & 495 & 1.218 & 0.619 & 0.211 & 0.096 & 0.241 & 1.503 \\
\hline $125 \%$ RDN & 7.67 & 507 & 1.228 & 0.629 & 0.221 & 0.096 & 0.251 & 1.526 \\
\hline $50 \% \mathrm{RDN}+50 \% \mathrm{~N}$ through FYM & 7.52 & 482 & 1.203 & 0.611 & 0.206 & 0.095 & 0.255 & 1.512 \\
\hline $\begin{array}{l}50 \% \text { RDN }+50 \% \mathrm{~N} \text { through FYM+ } \\
\text { Azospirillum }\end{array}$ & 7.80 & 542 & 1.247 & 0.633 & 0.229 & 0.098 & 0.262 & 1.546 \\
\hline $100 \%$ RDN through FYM & 7.45 & 441 & 1.192 & 0.605 & 0.193 & 0.096 & 0.228 & 1.479 \\
\hline Control (No fertilizer) & 7.37 & 320 & 1.197 & 0.593 & 0.184 & 0.092 & 0.224 & 1.465 \\
\hline SEm \pm & 0.04 & 5.24 & 0.0058 & 0.0006 & 0.0009 & 0.0006 & 0.002 & 0.0098 \\
\hline$C D(p=0.05)$ & 0.10 & 14.75 & 0.0162 & 0.0017 & 0.0025 & 0.0017 & 0.005 & 0.0277 \\
\hline
\end{tabular}

${ }^{*}$ DAT $=$ Day after transplanting

normal transplanting $\left(7.40 \%\right.$ and $\left.422 \mathrm{~kg} \mathrm{ha}^{-1}\right)$. This might be due to higher affectivity for nitrate reduction activities in source and catalyses enzyme 'protease' that are associates with synthesis of amino acid, a precursor for building block of protein in grains. These results were supported by (Krishna et al., 2008). Protein content in rice grain did not influenced significantly due to different hybrids (Table 4). However, rice hybrid 'Arize-6444' recorded significantly higher protein yield (482 kg ha-1) over 'PHB-71', respectively. Quality parameters are genetically governed and different cultivars haves different constituents which cannot be change, but can slightly be bio-fortified with agronomic practices. These results were 
supported by (Singh et al., 2013). Incorporation of $50 \%$ RND $+50 \% \mathrm{~N}$ through $\mathrm{FYM}+$ Azospirillum recorded significantly higher protein content and protein yield over rest of the treatments. However, both the inorganic treatments i.e. $100 \%$ and $125 \%$ RDN proved statistically at par with each other in regards to protein content and their yield. This may be due to the increased concentration of $\mathrm{N}$ in the grains, which might have modified the proportion of grain constitutions. These results are in close conformity with the findings of (Hossain et al., 2009; Davari and Sharma, 2010).

\subsection{NPK content, uptake and nutrient harvest index}

Transplanting of rice under SRI induced significant in bringing marked improvement in NPK content (Table 4) and their uptake in grain and straw with the total uptake margin was $20.14,3.64$ and $26.3 \mathrm{~kg} \mathrm{ha}^{-1}$ more over normal transplanting, respectively. Similar trends were also observed with regards to NPK harvest index (Table 5). Vigorously growing plants are able to absorb larger quantity of mineral nutrients

Table 5: Effect of crop establishment methods, hybrids and integrated nitrogen management on nutrient uptake and nutrient harvest index of rice (Pooled data of 2 years)

\begin{tabular}{|c|c|c|c|c|c|c|}
\hline \multirow[t]{2}{*}{ Treatments } & \multicolumn{3}{|c|}{ Total nutrient uptake $\left(\mathrm{kg} \mathrm{ha}^{-1}\right)$} & \multicolumn{3}{|c|}{ Nutrient harvest index (\%) } \\
\hline & Nitrogen & Phosphorus & Potassium & Nitrogen & Phosphorus & Potassium \\
\hline \multicolumn{7}{|l|}{ A. Crop establishment methods } \\
\hline Normal transplanting & 114.85 & 18.86 & 125.82 & 58.71 & 61.11 & 10.85 \\
\hline SRI & 134.99 & 22.50 & 152.12 & 59.89 & 61.95 & 10.62 \\
\hline SEm \pm & 0.770 & 0.213 & 1.186 & 0.216 & 0.260 & 0.129 \\
\hline $\operatorname{CD}(p=0.05)$ & 2.371 & 0.655 & 3.655 & 0.665 & 0.800 & NS \\
\hline \multicolumn{7}{|l|}{ B. Hybrids } \\
\hline PHB-71 & 120.98 & 20.13 & 135.92 & 59.01 & 61.10 & 10.68 \\
\hline Arize-6444 & 128.85 & 21.22 & 142.02 & 59.60 & 61.96 & 10.80 \\
\hline SEm \pm & 0.770 & 0.213 & 1.186 & 0.216 & 0.260 & 0.129 \\
\hline $\operatorname{CD}(p=0.05)$ & 2.371 & 0.655 & 3.655 & NS & 0.800 & NS \\
\hline \multicolumn{7}{|l|}{ C. Integrated nitrogen management } \\
\hline $100 \%$ RDN & 132.87 & 22.11 & 145.87 & 59.47 & 62.08 & 10.72 \\
\hline $125 \%$ RDN & 136.30 & 23.06 & 150.69 & 59.36 & 63.25 & 10.98 \\
\hline $50 \%$ RDN+50\% N through FYM & 129.00 & 21.29 & 145.18 & 59.68 & 62.02 & 11.32 \\
\hline $50 \%$ RDN+50\% N through FYM+Azospirillum & 144.78 & 24.85 & 160.17 & 59.86 & 63.92 & 11.39 \\
\hline $100 \%$ RDN through FYM & 118.50 & 19.01 & 130.77 & 59.44 & 59.84 & 10.36 \\
\hline Control (No fertilizer) & 88.05 & 13.75 & 101.14 & 58.01 & 58.05 & 9.66 \\
\hline SEm \pm & 1.059 & 0.198 & 1.380 & 0.299 & 0.333 & 0.137 \\
\hline$C D(p=0.05)$ & 2.982 & 0.558 & 3.883 & 0.842 & 0.938 & 0.387 \\
\hline
\end{tabular}

${ }^{*}$ DAT $=$ Day after transplanting

through well-developed root system. Larger root systems enable plants to access a greater volume of soil and to acquire more nutrients from various soil depths. Under aerobic soil conditions of SRI, root systems experience less deterioration and senescence. Aerobic soil conditions are generally more favourable for root functioning compared to anaerobic circumstances (Drew, 1997; Kirk and Solivas, 1997). A relatively higher increase of accumulated NPK in SRI planted crops as compared to their increase in conventionally planted rice. This can be further explained by regression analysis of rice grain yield with total NPK uptake for plants grown under both the environment was done assuming a polynomial relationship (Figure 3 ). This analysis indicated that with regard to NPK uptake, conventionally grown plants have a much faster decrease of internal efficiency. This decrease in grain production in response to marginal increases in nutrient uptake is expressed by the second degree of the parabolic equation having value of $r^{2}=0.956,0.929$ and 0.852 for normal transplanting and $r^{2}=0.947,0.927$ and 0.842 for SRI methods with $\mathrm{N}, \mathrm{P}$ and $\mathrm{K}$ uptake in response to grain yield (Figure 3 ). This means that increments to grain yield declined more rapidly in conventionally grown plants as these increased their uptake of nutrients compared with SRI plants. The difference in the respective abilities of these two categories of rice plant to convert the NPK taken up into grain yield reflects phenotypical divergence in terms of plant structure and physiology. Similar 
Rice grain yield response to $\mathrm{N}$ uptake

Grain yield NT $\left(\mathrm{kg} \mathrm{ha}^{-1}\right)$ Grain yield SRI $\left(\mathrm{kg} \mathrm{ha}^{-1}\right)$

----Poly. (Grain yield NT (kg ha-1))

- Poly. (Grain yield SRI (kg ha-1))

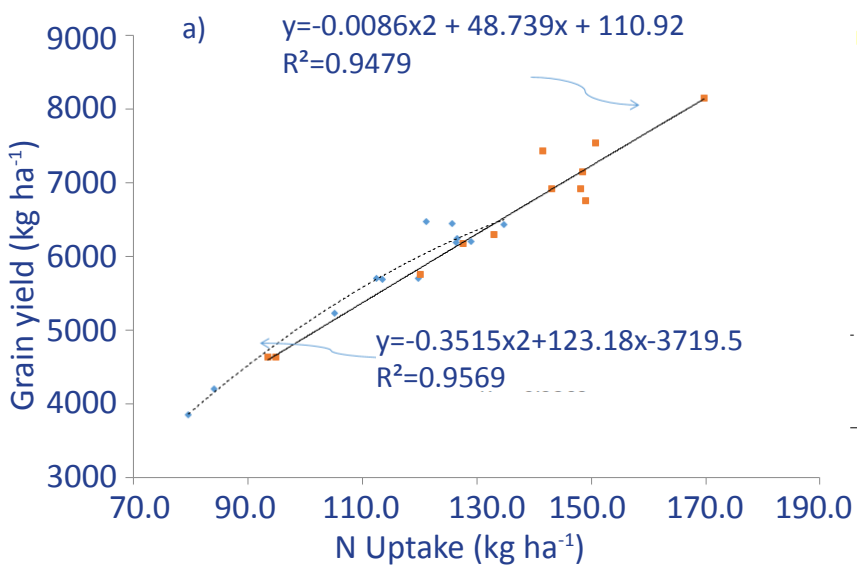

Rice grain yield response to $\mathrm{P}$ uptake

Grain yield NT $\left(\mathrm{kg} \mathrm{ha}^{-1}\right)$ Grain yield SRI $\left(\mathrm{kg} \mathrm{ha}^{-1}\right)$

---Poly. (Grain yield NT (kg ha-1))

-Poly. (Grain yield SRI (kg ha-1))

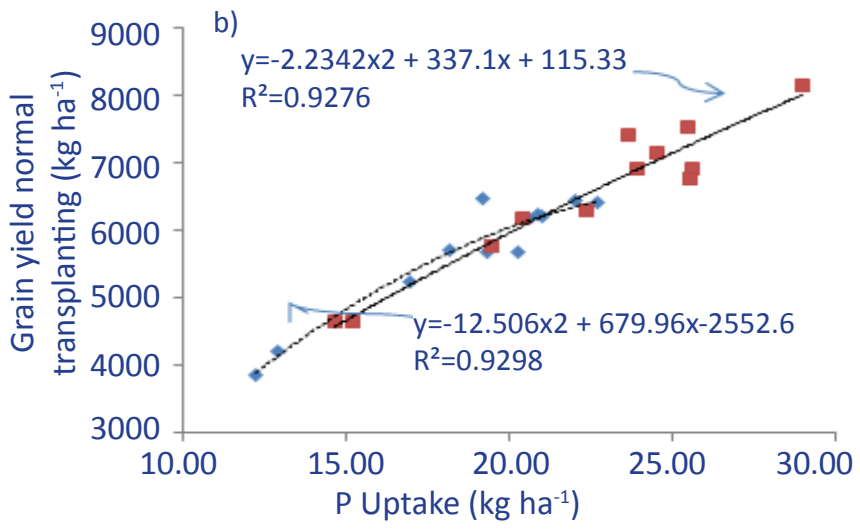

Rice grain yield response to $\mathrm{K}$ uptake

Grain yield NT $\left(\mathrm{kg} \mathrm{ha}^{-1}\right) \quad$ Grain yield SRI $\left(\mathrm{kg} \mathrm{ha}^{-1}\right)$

----Poly. (Grain yield NT $\left(\mathrm{kg} \mathrm{ha}^{-1}\right)$ )

c) - Poly. (Grain yield SRI $\left(\mathrm{kg} \mathrm{ha}^{-1}\right)$ )

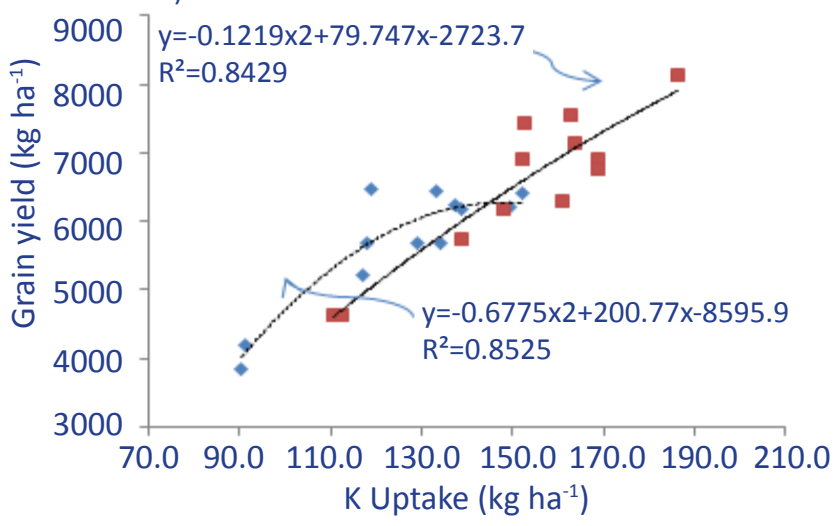

Figure $3(a, b, c)$ : Relationship between NPK uptake and grain yield of rice grown under normal transplanting (NT) versus SRI (Poly: polynomial regression line) findings were also reported by (Barison and Uphoff, 2011). NPK contents in grain and straw were not influenced significantly by hybrids except phosphorus content in straw and potassium content in grain, which were significantly higher under PHB71 over Arize-6444. Hybrids produced significant variation on NPK uptake in grain as well as straw. Higher NPK uptake in Arize-6444 showed its dominancy over PHB-71. Arize-6444 assimilated 7.87, 1.09 and $6.10 \mathrm{~kg} \mathrm{NPK} \mathrm{ha}^{-1}$ higher total uptake as compared to PHB-71. NK harvest index comparable at par to both the hybrids but Arize-6444 showed mark improvement in $\mathrm{P}$ harvest index over PHB-71.Similar findings were reported by (Singh et al., 2013; Gupta et al., 2011; Vishwakarma et al., 2016). The combined application of $50 \% \mathrm{RDN}+50 \% \mathrm{~N}$ through FYM+Azospirillum showed significantly higher NPK content and their uptake and harvest index over rest of the nitrogen management treatments but both the $50 \% \mathrm{~N}$ applied through FYM treated treatments remained statistically at par to each other in respect to $\mathrm{K}$ harvest index (Table 5). Moreover, all the nitrogen management options showed significant superiority over control. Furthermore, the application of $50 \%$ RDN $+50 \%$ $\mathrm{N}$ through FYM+Azospirillum recorded 56.73, 11.10 and $59.03 \mathrm{~kg} \mathrm{ha}^{-1}$ induced more total NPK uptake over control, respectively (Table 5). This might be due to increased supply of nutrients directly through organic and inorganic sources to the crop as well as indirectly through reducing the loss of nutrients from soil solution resulting in to better growth, higher biological yield as well as more nutrient concentration. Beneficial effect of farmyard manure and biofertilizer due to their mineralization and releasing profuse amount of nitrogen to the soil and checking downward movement of $\mathrm{N}$ making it available to the growing crop was also reported by (Pathak et al., 2005).

\section{Conclusion}

System of rice intensification (SRI) should be adopted with rice hybrid 'Arize-6444' for achieving its maximum yield, incorporation of $50 \%$ recommended dose of nitrogen through inorganic fertilizer and remaining 50\% N through FYM along with Azospirillum (bio-fertilizer) may be adopted under eastern Uttar Pradesh region.

\section{Acknowledgement}

The first author is grateful to Indian Council of Agricultural Research, New Delhi for the award of ICAR-Senior Research Fellowship as a financial assistance during Ph.D. programme to carry out this work.

\section{References}

Alim, M.A., 2012. Effect of organic, inorganic sources and doses of nitrogen fertiliser on the yield of boro rice. Journal of Environmental Sciences and Natural Resources 5(1), 273-282.

AOAC, 1970. Association of official analytical chemistry, Methods of analysis, (11 ${ }^{\text {th }}$ Edn.) Washington DC, 2044. 
Barison, J., Uphoff, N., 2011. Rice yield and its relation to root growth and nutrient-use efficiency under SRI and conventional cultivation: an evaluation in Madagascar. Paddy and Water Environment 9, 65-78.

Chandrapala, A.G., Yakadri, M., Kumar, R.M., Raj, G.B., 2010. Productivity and economics of rice- maize as influenced by methods of crop establishment, $\mathrm{Zn}$ and $\mathrm{S}$ application in rice. Indian Journal of Agronomy 55(3), 171-176.

Choudhary, R.L., Kumar, D., Shivay, Y.S., Anand, A., Nain, L., 2013. Yield and quality of rice (Oryza sativa) hybrids grown by SRI method with and without plant growth promoting rhizobacteria. Indian Journal of Agronomy 58(3), 430-433.

Dass, A., Baiswar, E.P., Patel, D.P., Munda, G.C., Ghosh, P.K., Chandra, S., 2010. Productivity, nutrient harvest index, nutrient balance sheet, and economics of low land rice (Oryza sativa) as influenced by compost made from locally available plant biomass. Indian Journal of Agricultural Sciences 80, 686-690.

Davari, M.R., Sharma, S.N., 2010. Effect of different combination of organic materials and biofertilizers on productivity, grain quality and economics in organic farming of basmati rice (Oryza sativa L.). Indian Journal of Agronomy 55(4), 290-294.

Drew, M.C., 1997. Oxygen deficiency and root metabolism under hypoxia and anoxia. Annual Review of Plant Physiology and Plant Molecular Biology 48, 223-250.

Gomez, K.A., Gomez, A.A., 1984. Statistical Procedures for Agricultural Research. John Wiley \& Sons, Singapore.

Gupta, R.K., Singh, V., Singh, Y., Singh, B., Thind, H.S., Kumar, A., Vashistha, M., 2011. Need-based fertilizer nitrogen management using leaf colour chart in hybrid rice (Oryza sativa). Indian Journal of Agricultural Sciences 81(12), 1153-1157.

Hayashi, H., 1995. Translocation, storage and partitioning of photosynthetic products. In: Marauo, T., Kumazawa, K., Ishii, R., Ishihara, K., Hirata, H., (Eds.), Science of the rice plant: Physiology 2, 546-565. Tokyo, Food and Agriculture Policy Research Centre.

Hossain, M.F., Bhuiya, M.S.U., Ahmed, M., Mian, M.H., 2009. Effect of organic and inorganic fertilizer on the milling and physicochemical properties of aromatic rice. Thai Journal of Agricultural Sciences 42(4), 213-218.

Islam, M.R., Sikder, S., Bahadur, M.M., Hafiz, M.H.R., 2012. Effect of different fertilizer management on soil properties and yield of fine rice cultivars. Journal of Environmental Sciences and Natural Resources 5(1), 239-242.

Jagtap, D.N., Sutar, M.W., Mahadkar, U.V., Chavan, S.A., Pinjari, S.S., Jadhav, M.S., 2018. Study of agrometeorological indices as affected by different duration rice varieties and crop establishment methods. International Journal of Bio-resource and Stress Management 9(6), 655-660. Doi: HTTPS://DOI.ORG/10.23910/IJBSM/2018.9.6.1894
Jat, A.L.,Srivastava, V.K. Singh, R.K., 2015. Effect of crop establishment methods and integrated nitrogen management on productivity of hybrid rice (Oryza sativa L.)-wheat (Triticum aestivum L.) cropping system. Indian Journal of Agronomy 60(3), 341-346.

Jat, A.L., Srivastava, V.K., Sen, A., Bohra, J.S., Maurya, B.R., Singh, R.K., 2016. Response of rice (Oryza sativa L.) hybrids to integrated nitrogen management under different methods of cultivation. Indian Journal of Agronomy 61(3), 331-335.

Kadiyala, M.D.M., Mylavarapu, R.S., Li, Y.C., Reddy, G.B., Reddy, M.D., 2012. Impact of aerobic rice cultivation on growth, yield and water productivity of rice- maize rotation in semiarid tropics. Agronomy Journal 104, 1757-1765.

Kirk, G.J.D., Solivas, J.L., 1997. On the extent to which root properties and transport through the soil limit nitrogen uptake by lowland rice. European Journal of Soil Science 48, 613-621.

Krishna, A., Biradarpatil, N.K., Manjappa, K., Channappagoudar, B.B., 2008. Evaluation of system of rice intensification (SRI) cultivation, seedling age and spacing on seed yield and quality in Samba Mashuri (BPT-5204) rice. Karnataka Journal of Agricultural Sciences 21(1), 20-25.

Lazaro, R., 2004. Water-saving high-yielding TQPM and SRI trial runs and demonstrations in the magballo-balicotoccanlamay integrated irrigation sub-project. Report from the Southern Philippines Irrigation Support Project to the National Irrigation Administration, Quezon City.

Lin, X., Zhou, W., Zhu, D., Zhang, Y., Yang, G., 2005. The photosynthetic rate and water use efficiency of leaves at different position at panicle initiation stage under the system of rice intensification (SRI). China Journal of Rice Science 19, 200-206.

Manjunatha, B.N., Basavarajappa, R., Pujari, B.T., 2010. Effect of age of seedlings on growth, yield and water requirement by different system of rice intensification. Karnataka Journal of Agricultural Sciences 23(2), 231-234.

Miyazato, T., Mohammed, R.A., Lazaro, R., 2010. Irrigation management transfer (IMT) and system of rice intensification (SRI) practice in the Philippines. Paddy Water Environment 8(1), 91-97.

Pandey, N., Verma, A.K., Anurag, Tripathi, R., 2007. Effect of integrated nutrient management in transplanted hybrid rice (Oryza sativa). Indian Journal of Agronomy 52(1), 40-42.

Pathak, S.K., Singh, S.B., Jha, R.N., Sharma, R.P., 2005. Effect of nutrient management on nutrient uptake and changes in soil fertility in maize-wheat cropping system. Indian Journal of Agronomy 50(4), 269-273.

Pillai Shalini, P., Geethakumari, V.L., Sheeba Rebecca, I., 2007. Balance-sheet of soil nitrogen in rice (Oryza sativa)based cropping systems under integrated nutrient management. Indian Journal of Agronomy 52(1), 16-20. 
Prasad, R., Nagrajan, S., 2004. Rice-wheat cropping system: food security and sustainability. Current Science 87(10), 1334-1335.

Rakshit, A., Sarkar, N.C., Debashish, S., 2008. Influence of organic manures on productivity of two varieties of rice. Journal of Central European Agriculture 9(4), 629-634.

Redford, P.T., 1967. Growth analysis formulae- Their use and abuse. Crop Science 7, 171-175.

Sangeetha, S.P., Balakrishnan, A., Bhuvaneswari, J., 2010. Organic nutrient sources on growth and yield of rice. Madras Agricultural Journal 97(7-9), 251-253.

Saravanakumar, S., 2020.Integrated nitrogen management in rice (Oryza sativa) under system rice intensification. Indian Journal of Agricultural Sciences 90(5), 843-846.

Satyanarayana, A, Thiyagarajan, T., Uphoff, N., 2007. Opportunities for water saving with higher yield from the system of rice intensification. Irrigation Science 25(2), 99-115.

Shukla, U.N., Srivastava, V.K., Singh, S., Ram, U.S., Pandey, A.K., 2015. Effect of seedlings age, cultivars and weed management on weed dynamics, nutrient removal and yield of rice (Oryza sativa) under system of rice intensification (SRI). Indian Journal of Agricultural Sciences 85, 1260-1268.

Shu-Qing, C., Rong-Xian, Z., Wei, L., Zhi-Rui, D., Qi-Ming, Z., 2004. The involvement of cytokinin and abssicic acid levels in roots in the regulation of photosynthesis function in flag leaves during grain filling in super highyielding rice (Oryza sativa). Journal of Agronomy 90, 73-80.
Singh, K., Singh, S.R., Singh, J.K., Rathore, R.S., Pal, S., Singh, S.P., Roy, R., 2013. Effect of age of seedling and spacing on yield, economics, soil health and digestibility of rice (Oryza sativa) genotypes under system of rice intensification. Indian Journal of Agricultural Sciences 83(5), 479-83.

Singh, Y.V., 2013. Crop and water productivity as influenced by rice cultivation methods under organic and inorganic sources of nutrient supply. Paddy Water Environment 11, 531-542.

Thakur, A.K., Rath, S., Mandal, K.G., 2013. Differential responses of system of rice intensification (SRI) and conventional flooded-rice management methods to applications of nitrogen fertilizer. Plant and Soil 370, 59-71.

Thakur, A.K., Uphoff, N.T., Stoop, W.A., 2016. Chapter Four -Scientific Underpinnings of the System of Rice Intensification (SRI): What Is Known So Far?. Advances in Agronomy 135, 147-179.

Vishwakarma, A., Singh, J.K., Singh, R.K., Jat, A.L., 2016. Productivity and profitability of rice (Oryza sativa) hybrids as influenced by date of transplanting and age of seedling under system of rice intensification. Indian Journal of Agronomy 61(3), 315-320. 